\title{
6D-model of business valuation management: actuarial aspect
}

\author{
Svitlana Luchyk \\ Chernivtsi Institute of Trade and \\ Economics of Kyiv National University \\ of Trade and Economics \\ Kyiv National University of Trade and \\ Economics \\ Chernivtsi, Ukraine \\ luchiksvitlana@gmail.com \\ http://orcid.org/0000-0003-0757-1140 \\ Marharyta Luchyk \\ Kyiv Cooperative Institute of Business \\ and Law \\ Kiev, Ukraine \\ Luchik-margarita@ukr.net \\ http://orcid.org/0000-0002-4822-5407
}

\author{
Yulia Manachynska \\ Chernivtsi Institute of Trade and \\ Economics of Kyiv National University \\ of Trade and Economics \\ Kyiv National University of Trade and \\ Economics \\ Chernivtsi, Ukraine \\ yu_manachynska@ukr.net \\ http://orcid.org/0000-0001-9155-3417
}

\author{
Volodymyr Yevdoshchak \\ Chernivtsi Institute of Trade and \\ Economics of Kyiv National University \\ of Trade and Economics \\ Kyiv National University of Trade and \\ Economics \\ Chernivtsi, Ukraine \\ V_Yevdoshchak@ukr.net \\ http://orcid.org/0000-0001-6547-8927
}

Abstract-The article is devoted to new trends and tasks of managing economic business value by the means of multidimensional innovation accounting model under the terms of integration strategies implementation. 6D model of business value management is offered on the basis of actuarial accounting and accountancy with the help of convolution block of 3D, 4D, 5D-formats of accounting interpretation of the results of financial and economic activity of market entity. The first block of the model in $3 \mathrm{D}$ - format contains traditional financial accountancy transformed in 3D based on foreign approach involving high-quality human resources for the specified procedure. The second one is $4 \mathrm{D}$ format $(3 \mathrm{D}+\mathrm{time})$ which consists of actuarial accountancy to an appropriate perspective (time lag ( $t)$. The 5D format of accounting information parameterization is proposed for the third block, which includes the development of a system for assessing business value based on the 4D model and provides an increase in its level of investment prospects in the financial market. The proposed 6D model includes investments and effective management system involved in business development by financial resources. Presented multidimensional model of business value management based on an actuarial basis can be used by business entities to emerge financial crisis regardless of the economy sector of Ukraine. The calculated results of accounting and information content of the 6D-model can be used in the decision-making system as a complete foundation for the development of integration strategies of enterprises, as well as an effective lever for attracting the necessary amount of investment in their socio-economic development.

Keywords-management, strategy, economic system, business value, actuarial accounting, $6 D$-model.

\section{INTRODUCTION}

New trends in the management of economic systems put forward their requirements for the developing and implementing integration strategies. The direct choice of the enterprise of the corresponding strategy involves a certain consolidated model of action, aimed at the implementation of the life cycle of the identified initial goals, achieved through rational consumption of available resource potential.
However, during crisis in the domestic economy, the problem of attracting the required amount of investment in business development requires urgent resolution. Accordingly, existing business models based on integration strategies of enterprise management also require rethinking in terms of facilitating investment in parametrization of multidimensional business process. Foreign experience shows that the highest quality content that contributes to increasing the level of investment attractiveness of the company is contained in actuarial accountancy. Therefore, the development of 6D model of business value management with an actuarial perspective becomes a strategic priority for companies facing financial difficulties.

$\mathrm{N}$-dimensional business model of companies through the prism of actuarial accounting is the object of the study.

Theoretical foundations and methodical tools for forming the 6D model of business value management based on actuarial aspect are the subject of the research.

Significant contribution to the development of theoretical and methodological foundations of the formation and implementation of integration strategies in the context of business value management has been made by famous scientists such as K. Blischuk, L. Chorna, E. Kamishnikova, I. Kozak, R. Lupak, L. Maliuga, N. Skopenko, L. Smoliy, O. Sophia, V. Turchak, T. Vasil'tsev, O. Zagorodniuk. In particular, Skopenko, N. (2014) exploring the features of the development of integration interaction of Ukrainian enterprises, draws attention to the fact that the world and domestic economy are forming a new development paradigm.

The basis of such paradigm is the growing interrelation between socio-economic development of the society and integration processes. According to the domestic scientist, the expansion of integration interaction between market entities and creation and functioning of integration structures becomes leading factor and key to economic growth [1]. 
Issues of strategic management of corporate approaches to enterprise management based on business models become especially relevant at the macro level. In particular, E. Kamishnikova, (2017) points out one of the priority areas of cooperation with key stakeholder groups to choose the introduction of the concept of corporate social responsibility (CSR) into the overall enterprise strategy [2].

The process of creating and distributing business value among stakeholders accumulated in innovative business management models is necessary to enhance its competitiveness as well as the effective conversion of attracted financial investments.

In turn, T. Vasil'tsev, R. Lupak, (2018) pay special attention to the disclosure of directions and tools of state policy of strengthening the competitiveness of domestic enterprises in the Ukrainian market. In particular, scientists place the financial and investment direction among the primary strategic tasks of the market entity. The core of this area is rational and efficient use of both internal and external financial resources of the enterprise, including the implementation of investment support for innovative activities. In turn, the rational use of financial and investment resources by the enterprise requires strategic planning and reorientation of the management system [3].

L. Smoliy, O. Zagorodniuk, L. Maliuga (2017) are pointing out a dynamic economic and mathematical model for optimizing investment of enterprise technical support. This model determines optimal alternative options for the implementation of investment projects in terms of four optimization criteria. According to domestic scientists, the practical implementation of such a model will help to optimize making effective economic decisions at enterprises in terms of allocation of attracted investment resources, which in complex will ensure the formation of a rational investment portfolio [4].

V. Turchak, (2017) offers an innovative approach to strategic management of international activities. The scientist thoroughly and comprehensively studies the international division of labor and substantiates new requirements for the enterprise management system and long-term strategic managerial tools. Among the stages of strategic planning of international activity of the enterprise, the scientist distinguishes the analysis of economic potential of the enterprise, which is closely interrelated with the justification of its competitive advantages [5].

At the same time, there are not scientific papers that would highlight the need to develop innovative practices for cost-effective $6 \mathrm{D}$ business model implementation by enterprises. Approaches to structural elements of competitive n-dimensional business models in 3D, 4D, 5D, 6D formats based on the actuarial basis are needed, which will help to increase the investment attractiveness of companies and their development in order to facilitate the mechanism of implementation of business managerial strategy.

\section{METHODS}

Main results of the study were obtained using general scientific and specific research methods. Methods of systematization, generalization, analysis, synthesis, logical research, systematic approach, and modeling are applied for studying and development of theoretical backgrounds, development of theoretical and methodological bases of 6Dmodel of business value management. Using the methods of expert assessments, the analysis of "Ukraine - 2030" strategy was carried out which emphasizes the vector of EU integration development. Actuarial accounting methods - 5D actuarial financial accountancy - to build the second block of $6 \mathrm{D}$ business model of enterprise value management based on the actuarial aspect. The method of estimating the enterprise value - when forming the third block of the proposed 6Dbusiness model based on $4 \mathrm{D}$-format $(3 \mathrm{D}+\mathrm{t})$. Statistical survey methods were used to analyze the qualification characteristics of Ukraine's labor resources potential in the labor market.

\section{RESULTS}

Objective expert evaluation of "Ukraine - 2030" strategy: the vector of development - EU integration, shows that "Ukraine - 2020" strategy rather briefly points to the main vectors of Ukraine's development, contains all the reforms and programs whose practical implementation should be completed by 2020. However, the Strategy contains 25 indicators that measure the progress of the reforms, but their practical implementation requires a much longer time, as there are only 5 key indicators in the Europe2020 Strategy, but this optimal number ensures the achievement of the priority objective aimed at the development of personality and intellectual support [6]. We agree with the opinion of domestic experts-analysts, because sometimes it is important to optimize the initial parameters at the initial stage of business model in order to achieve the ultimate goal of functioning of the enterprise in the capital markets more easily.

In our opinion, management system of modern enterprise value should be built on a priority new innovation strategy, which comprehensively takes into account the spatial interpretation of multidimensional business processes occurring in the enterprise and contributes to increasing its level of investment attractiveness in the market, i. e. attracting financial resources from domestic or foreign investors.

3D, 4D, 5D, 6D... .nD (from Eng. Dimension (D) number of independent dimensions) - formats have become quite commonplace for the vast majority of socio-economic phenomena and processes in society.

Due to the multidimensionality of space, it is possible to see new trends in the management of economic systems in terms of implementation of integration strategies comprehensively.

For the modern management system of enterprise value, we offer to apply our 6D model, which is based on the innovative actuarial subsystem and uses sophisticated methodological tools of actuarial mathematics and probability theory. The latter requires intellectual and personnel support, for further practical implementation of the model in practice, Fig. 1.

From Fig. 1 it is noticeable that 6D management model includes a block convolution of 3D, 4D, and 5D formats of accounting interpretation of the results of financial and economic activity of the enterprise. An innovative 6D 
management model of business value is an important tool for effective strategic assessment of its long-term economic potential.

6D model incorporates a comprehensive, multidimensional interpretation of business processes that reflects transformation of an enterprise's financial accountancy potential from 3D into 5D actuarial financial statements in order to enhance its investment attractiveness in the financial market and is implemented by highly qualified personnel to perform the specified procedure. tetrahedron face. This provides a visual representation of accountancy forms interrelation of the reporting forms.

The second - 4D format $(3 \mathrm{D}+$ time $)$ includes actuarial accountancy for the relevant perspective (time lag $(t)$. The latter is based on the financial statements in 3D and contains accounting information about the prospects for changes in financial and operating assets and liabilities Thus, actuarial accountancy contains important information for real and potential investors who plan to invest temporary free financial resources in the further development of the enterprise.

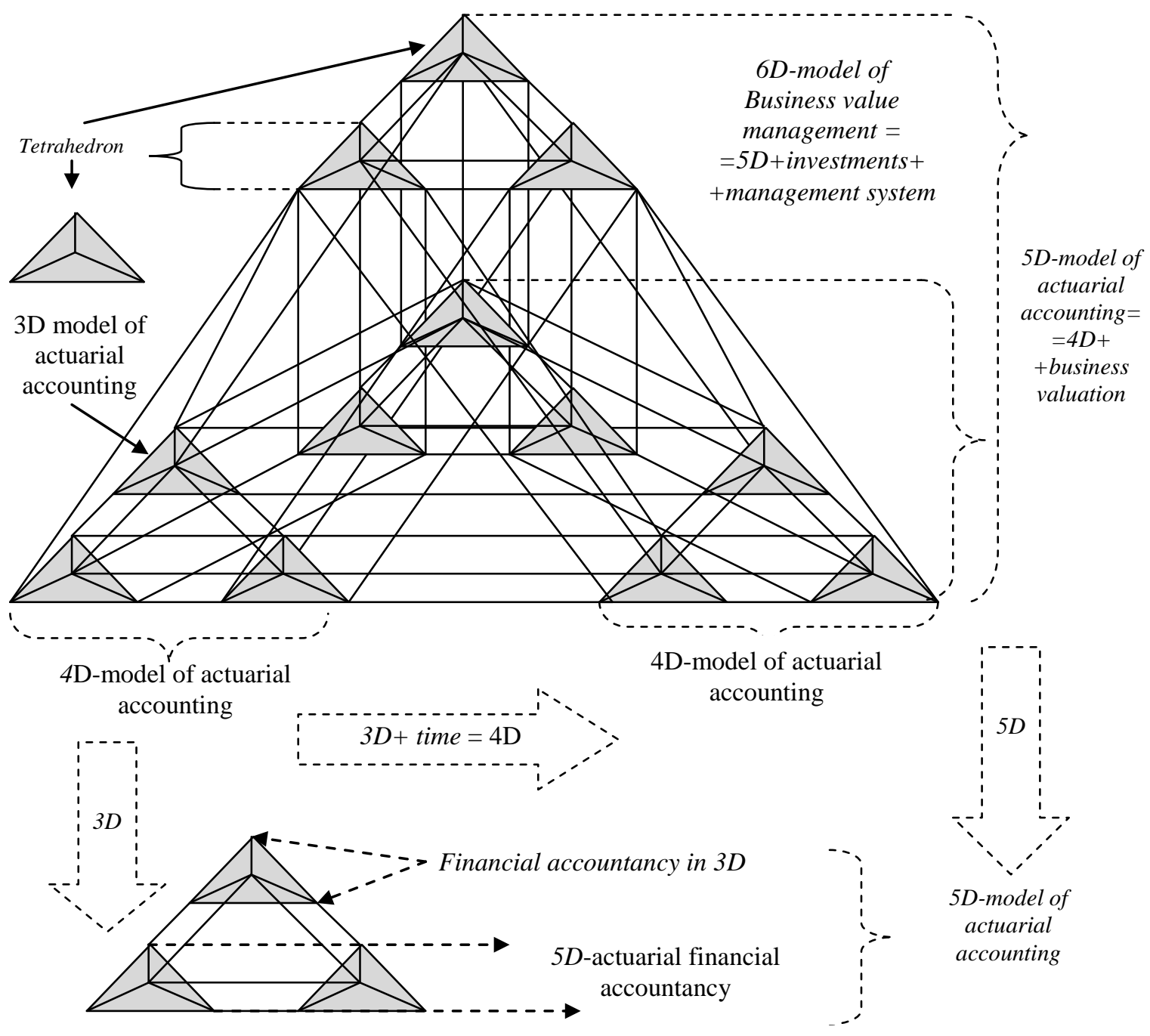

Fig. 1. 6D-model of business valuation management: actuarial aspect.

The first block of the model in 3D format contains the traditional financial statements transformed into 3D based on a foreign approach with the involvement of highly skilled intellectual human resources for carrying out the specified procedure. In Fig. 1, this block is in the form of a regular tetrahedron - a simple polyhedron whose sides are four triangles, in other words a triangular pyramid. In a multidimensional accounting system, the appropriate form of financial accountancy in $3 \mathrm{D}$ is placed in a separate
For the third block, a 5D format of accounting information parameterization is offered, which includes the development of an enterprise value system based on 4D model and enhances its level of investment attractiveness in the financial market.

The fourth block - 6D - complements 5D format with the already attracted amount of investments and an effective system of financial resources management by the means of 
high-quality top-level managers within the implementation of the defined enterprise integration strategy.

Offered multidimensional 6D model of business value management with actuarial backgrounds can be used by domestic companies to overcome their financial crisis regardless the sector of Ukrainian economy by increasing their level of investment attractiveness in the financial markets.

An effective management system, under modern conditions, should be based on new innovative approaches to dimensional interpretation of the results of financial and economic activity of the company from the actuarial accounting system in $3 \mathrm{D}, 4 \mathrm{D}, 5 \mathrm{D}$ and $6 \mathrm{D}$ formats. $6 \mathrm{D}$ generalization of accounting information itself will provide the proper level of business value management based on innovative methodological tools for actuarial accounting. In turn, actuarial methodological tools will facilitate the implementation of systemic changes, in particular by increasing the level of investment attractiveness, as well as the proper intellectual and human resources of enterprises.

One of the most important issue in the performance of any enterprise is the availability of the necessary intellectual and human resources in sufficient quantity and proper quality. According to a study conducted by Rita Almedia with Pedro Carneiro, income rate on capital invested by the company into the education and training of staff is $8.6 \%$ [7].

The population of Ukraine is characterized by a rather high educational level. In particular, the share of employed population with higher education is $38.9 \%$ in formal and $13.0 \%$ in the informal sector [8]. According to Bloomberg, in terms of education, our country ranks 6 th in the world, that is, in the top ten. Almost $90 \%$ of our school graduates enter universities [9]. However, experts are surprised that such significant intellectual and human resources are not able to improve economy of the country. According to Global Competitiveness Index 2018, Ukraine ranks 66th in terms of the labor market, $117^{\text {th }}$ in financial system, $86^{\text {th }}$ in business dynamics, $58^{\text {th }}$ in innovation. We believe that education should be highly valued in society and monetized in the career development of employees, and employees' education is a promising area of investment for enterprises.

Professional experience in management comprehension is closely intertwined with nonstop professional development. Preference at the interviews with employers is obtained by those specialists who have diplomas and certificates confirming the relevance of knowledge in the field of accounting, tax and management accounting, financial management, internal audit, actuarial mathematics, etc. However, in Ukraine over the last decade the indicator of personnel professional development remains at the middle positions - 3.4 - 3.9 points. For comparison, in Germany this figure is consistently above 5 points, which shows high ability of employees to innovate [11]. The State Statistics Service of Ukraine has not published data on vocational training and advanced training of employees since 2014.

Specialist's rapid adaptation to external changes is also a skill that is in demand today and has not been appreciated by employers until recently.
Therefore, in order to be competitive and in demand, to meet the requirements of modern business in accordance with international standards, an accountant should go beyond accounting functionality and learn to think on a global scale based on an actuarial backgrounds. It is not just limited to submitting financial statements, but to build the financial policy of the company. The accountant is aware of the financial status of economic entity, he can not only judge managerial decisions, but also participate in making and implementation of these decisions.

Involvement of such professional accountants (actuarial accountants) is required by the third block of our 6D managerial model of business value, which includes actuarial financial reporting in $4 \mathrm{D}$ format $(3 \mathrm{D}+$ time). Based on this model the process of enterprise valuation is carried out quite quickly (covering only two stages) and 5D format of interpretation of accounting information is formed. In turn, our 3D-based, 4D-actuarial accountancy creates the necessary information on the prospects for changing business value. That is, 4D actuarial reporting is able to interest a potential investor and enhance the image of investment attractiveness of business entity.

It should be noted that Ukraine's investment attractiveness index, which is measured twice a year by the European Business Association (EBA), decreased to the level of 2016 in the first half of 2019. The index was 2.85 points out of 5 and was negative. The amount of foreign direct investment in Ukraine in 2010-2018 decreased by $\$$ 4140 million. Moreover, at the end of 2018 accounted for \$ 2355 million. USA. During the first half of 2019 Ukraine received \$484 million [13]. Mostly foreign companies invest in manufacturing, financial, and real estate business, where costs are recouped more quickly, any long-term capital investment is needed, and low commercial risks are present. However, the development of national economy requires considerable investment in high-tech production, which would enable the country to strengthen and expand its export potential and move from a commodity economy to a hightech one. The available domestic intellectual and human potential allows us to do so.

Moreover, an important advantage of practical implementation of an innovative 6D managerial model of business value at domestic enterprises is the creation of a favorable basis for their entry into international financial markets and the provision of an effective mechanism for implementing innovative managerial strategies.

\section{DISCUSSION}

Above presented multidimensional 6D actuarial model of business value management can be used by economic entities to overcome their financial crisis regardless any sector of Ukrainian economy. Calculated results of 6D model can be used in decision-making system as a full-fledged foundation for the development of enterprise integration strategies, as well as an effective lever for attracting the necessary volume of investments in their socio-economic development. In turn, sufficient level of intellectual and human resources will facilitate the active implementation of 6D-model in operation of economic activity of domestic companies and will ensure the implementation of new trends in the management of economic systems under the terms of integration strategies. 
In our opinion, modern business managerial models do not take into account the uncertainty of the production capacity of companies, so they need improvement by introducing modern managerial and information technologies in order to facilitate crisis overcome by business. In addition, to creating an effective management system of an enterprise, a systematic situational approach and detailed development of an integrated business strategy should be actively implemented to specific stages of its implementation. Therefore, we believe that theoretical substantiation of our multidimensional 6D model requires implementation in the environment of modern accounting software.

As it was stated above, in the business value management model, allocation and use of attracted investment is achieved through an efficient managerial system that is a part of the fourth block and which provides an adequate level of return on invested capital. After all, our 6D model comprehensively contributes to overcoming financial difficulties and manifestation of crisis tendencies of an enterprise. This is achieved because through the prism of 5D-actuarial accountancy a favorable information base is created to evaluate the prospects of changing the economic value of the enterprise for the long-term perspective, which is of primary interest to the investor. 5D actuarial accountancy form provides capital suppliers with timely information on changes in the absolute amount of operating and financial assets and liabilities, as well as equity funding. That is, unlike the existing approaches, our 6D model of business value management helps us to increase the level of investment attractiveness of the company in the market. After all, the accounting content of 5D-actuarial financial accountancy can be interesting to both internal and external real and potential investors, as it contains detailed information about the value created by the company, the dynamics of future cash, which is able to meet the needs of business owners and senior management.

\section{CONCLUSIONS}

6D business model has the following areas of its practical implementation: demonstration of the level of business investment attractiveness through the prism of 5D-actuarial financial accountancy; training staff in actuarial calculations and actuarial accounting and further assess the economic potential of the company; creation of the mechanism of business strategy implementation with its detailed substantiation; effective promotion of business sale as a complete property complex (CPC); understanding the role of intellectual capital (human resources and intellectual property) of the company for building an effective business management system; optimization of algorithm of realization of business value estimation.

Abovementioned areas of practical implementation of 6D business model of business value management, taking into account the actuarial basis, cover the key aspects of the company's operation, which depend on its long-term success in the market.

In general, according to the results of conducted study of $6 \mathrm{D}$-model of business value management, it is worth noting that this business model comprehensively optimizes the algorithm of estimating the economic potential of an enterprise based on 5D-actuarial accountancy. Due to this higher level of efficiency of its application in practice compared to traditional methods of estimating the value of an enterprise, based on a rather time-consuming algorithm of its implementation, which has more than ten stages. Structural elements of $6 \mathrm{D}$ business model in 3D, 4D and 5D formats based on the actuarial basis, help to increase the investment attractiveness of companies and their development towards the implementation of business strategy in long-term business value managing. Complementation, on a remote basis, of 6D model with such component as facility management (FM), will provide a mechanism for integrated management of the enterprise infrastructure and will serve to form the next 7D dimension of innovative business model, the latter outlines the prospects for further exploration within the selected issues.

\section{REFERENCES}

[1] N. Skopenko, "Features of the development integration cooperation of food industry enterprises in Ukraine", Bulletin of the Taras Shevchenko National University of Kyiv, vol. 5, pp. 28-32, 2014.

[2] E. Kamishnikova, "Integration of Corporate Social Responsibility into Corporate Strategy", Economic Analysis, vol. 27, no.1, pp. 199-205. 2017.

[3] T. Vasil'tsev, and R. Lupak, "Directions and tools of the state policy of strengthening the competitiveness of domestic enterprises in the internal market of Ukraine", in Proc. 19th Intern. Conf., Kiev, 2018, pp. 6-8.

[4] L. Smoliy, O. Zagorodniuk, and L. Maliuga "Modelling of investment decisions on technical support of agricultural enterprises", Economic Annals-XXI, vol. 163, no.1, pp. 79-84, 2017.

[5] V. Turchak, "Formation of the strategy of international activity of the enterprise", Young Scientist, vol. 3, no.43, pp.863-866, Mar, 2017.

[6] Strategy Ukraine-2030: Development vector - integration into the EU, 2019. [Online]. Available: https://bloggers4gg.org.ua/2019/05/strategiya-ukra\%D1\%97na-2030vektor-rozvitku-integraciya-v-yes/ Accessed on: June, 15, 2019.

[7] E. Khmelevskaya "Investments in human capital", Strategic business review, [Online]. Available: http://www.sbr.in.ua/?p=2111. Accessed on: June, 25, 2019.

[8] Economic activity of population in Ukraine in 2017. State Statistics Service of Ukraine, 2018. [Online]. Available: http://www.ukrstat.gov.ua/druk/publicat/kat_u/2018/zb/07/zb_EAN_2 017.pdf Accessed on: June, 23, 2019.

[9] Ukraine is the leader among the countries of Europe for ... poverty! In the other rankings, the back passes, 2019. [Online]. Available: https://panoram.com.ua/news/reyting-ukrainy/ Accessed on: June, 27, 2019.

[10] T. Vasil'tsev, O. Rudkovskii, and S. Rudik "Management of intellectual and personnel support of leadership development in enterprises of the internal consumer market", Business Inform, vol. 11, no 5, pp.489-493, 2017.

[11] The Global Competitiveness Report, 2018. [Online]. Available: http://reports.weforum.org/global-competitiveness-report-2018/ Accessed on: June, 29, 2019.

[12] L. Golden, Financial reporting in 3d, Super Publishing, 2016.

[13] Ministry of Finance, 2019. [Online]. Available: https://index.minfin.com.ua/ua/economy/fdi/ Accessed on: June, 25, 2019. Accessed on: June, 29, 2019.

[14] L. Chorna, "Trends in the development of management of a modern enterprise, Agrosvit, vol. 5, no.9, pp.16-20, 2018.

[15] K. Blischuk, and I. Kozak, "Formation of Strategic Priorities for Regional Development in Regulatory Documents," Efficiency of Public Administration, vol. 3, no.52, pp. 225-233, 2017. 